\title{
Ameliorative effect of aqueous seed extract of delonix regia on hyperglycemia, liver function and lipid profile levels in Streptozotocin induced Diabetic Male wistar rats
}

\begin{abstract}
Diabetes mellitus is a major global health concern with a projected rise in prevalence from 171 million in 2010 to 366 million 2030. Thus, the objective of the present study was to investigate the antidiabetic ability of aqueous seed extract of delonix regia on streptozotocin induced diabetic male wistar rats. A total of 24 male wistar rats between the weights of $110-135 \mathrm{~g}$ were used and grouped into four $(\mathrm{n}=6)$. All experimentations were conducted using standard methods and our findings shows that $50 \mathrm{mg} / \mathrm{kg}$ intraperitoneal streptozotocin injection caused hyperglycemia as the experimental groups significantly $\mathrm{p}<0.05$ had elevated blood sugar levels $222.00 \pm 5.18$, $225.00 \pm 4.52$ and $224.50 \pm 4.72$ respectively relative to the normal control $90.50 \pm 3.33$. Liver function enzymes (ALT, ALP and AST), lipid profile triad (CHOL, TRIG, HDL) were significantly $\mathrm{p}<0.05$ elevated except for HDL which decreased for negative control relative to the normal control. However, $300 \mathrm{mg} / \mathrm{kg}$ aqueous seed extract of delonix regia treatment for the period of 21 days significantly $\mathrm{p}<0.05$ aided blood sugar levels reduction, improved the levels of liver function enzymes and acted as a good regulator of lipid profile.
\end{abstract}

Keywords: diabetes mellitus, delonix regia, streptozotocin, liver enzymes, lipid profile
Volume 7 Issue 3 - 2019

\author{
Nwawuba SU,' Monago CC, ${ }^{2}$ Mejulu $\mathrm{KC}^{\prime}$ \\ 'Department of Biochemistry, Faculty of Science, Madonna \\ University Okija, Nigeria \\ ${ }^{2}$ Department of Biochemistry, University of Port Harcourt, \\ Nigeria
}

\begin{abstract}
Correspondence: Nwawuba Stanley Udogadi, Department of Biochemistry, Faculty of Science, Madonna University Okija, Elele Campus, River State, Nigeria, Tel +234-8065699068,
\end{abstract} Email nwawubastanley@gmail.com

Received: May 21, 2019 | Published: June 10,2019

\section{Introduction}

Diabetes Mellitus (DM) is a serious, chronic disease that occurs either when the pancreas does not produce enough insulin (a hormone that regulates blood sugar, or glucose), or when the body cannot effectively use the insulin it produces. Diabetes is an important public health problem, one of four priority non-communicable diseases (NCDs) targeted for action by world leaders. Both the number of cases and the prevalence of diabetes has steadily being on the increase over the past few decades ${ }^{1}$ and it is reported to be a silent killer disease and affects millions of peoples in the world. ${ }^{2}$ DM has spread widely, not only in high-income countries (HICs) but also in many low- and middle-income countries (LMICs) over recent decades. ${ }^{3}$ Reports from the International Diabetes Federation (IDF) shows that diabetes affected 382 million people worldwide in 2013, a number that is expected to rise to 592 million by 2035.4

Regardless of the numerous conventional medications that have been in use for the management of DM, it inaccessibility has been a limitation as a result of the relatively high cost and sometimes unavailability. In this light, of course a switch to a readily available and cheaper alternative has become necessary in the form of phyto/ herbal medicine. Herbal medicine also known as phytomedicinerefers to the use of plants seeds, flowers, roots for medicinal purpose and even today plant materials continue to play a major role in primary health care as therapeutic remedy in many developing countries ${ }^{5}$ and recently, the World Health Organization (WHO) recommended the use of medicinal plants for the management of DM and further encouraged the expansion of the frontiers of scientific evaluation on the hypoglycemic properties of diverse plant species. ${ }^{6}$
Delonix regia is a plant from the family Leguminosae, is extensively cultivated in most regions of the world. Sometime known as royal Poinciana may flower plant or flamboyant, many branched, broad, spreading, flat crowned deciduous tree and well known for its brilliant display of red orange bloom, literally covering the tree from May to June. ${ }^{5} D$. regia has folkloric been used as a medicinal agent to treat some disorders, such as constipation, inflammation, rheumatoid arthritis, diabetes, pneumonia, and malaria. ${ }^{7}$ Many biological activity substances in the seed extracts of $D$. regia were reported to have antimalaria property, ${ }^{8}$ wound healing agent in household, ${ }^{9}$ antidiabetic ${ }^{10}$ and antioxidant property. ${ }^{11}$ These functional phytoconstituents exist in leaves, flowers, barks, and seeds of $D$. regia including flavonoids, alkaloids, saponins, sterols, $\beta$-sitosterol, lupeol, tannins, carotenoids, and phenolic acids. ${ }^{7}$ Diabetes prevalence has been projected to be on the increase and this situation demands that continually evaluation and scientific validation of phytomedicine should also increase so as to cushion the predicament. The seed extract of $D$. regia at lethal dose LD (50) index for acute toxicity has been demonstrated not to be toxic ${ }^{12}$ and as such, the present study aims to evaluate the effect of aqueous seed extract of $D$. regia on streptozotocin induced diabetic male wistar rats.

\section{Material and methods}

\section{Plant collection and preparation}

The seeds of Delonix regia were collected from the surrounding fields of Madonna University Elele campus and identified by Professor Obute in the department of Ethnobotany University of Port-Harcourt. The seeds were washed, dried under room temperature for a period of 
two (2) weeks and then pulverized into a fine powder. D. regia seed powder $600 \mathrm{~g}$ was extracted in the cold by maceration in water for $72 \mathrm{~h}$, filtered using Whatman filter paper and filtrate was then condensed and evaporated to dryness using a rotary evaporator and water bath at $50^{\circ} \mathrm{C}$. The extract of $120 \mathrm{~g}$ yield in an air tight bottle was then stored in the refrigerator for further use.

\section{Animal}

A total of 24 male wistar rats between the weights of 110-135g were procured from the animal house, department of physiology, Madonna University, Nigeria for this study and were allowed to acclimatize for two weeks before commencement of experimentation. They male wistar rats were kept in well kempt and ventilated cages and their beddings changed every three days and they were fed rat normal pellet diet and allowed free access to clean drinking water. All the processes involved in the handling and experiment were carried out according to standard protocols approved by the animal ethics committee of the department of Biochemistry Madonna University.

\section{Induction of experimental diabetes mellitus with streptozotocin}

Diabetes was induced by single dose intraperitoneal injection of $50 \mathrm{mg} / \mathrm{kg}$ streptozotocin (Sigma Chemical, St Louis, MO, USA) dissolved in a citrate buffer $(0.1 \mathrm{M}, \mathrm{pH} 4.5)$ and after 72 hours blood samples were collected from caudal vein for determination of fasting blood sugar level using ACCU-CHEK Glucometer. Rats with values between $(224-225 \mathrm{mg} / \mathrm{dl})$ were considered diabetic and $(90-99 \mathrm{mg} / \mathrm{dl})$ were considered normal in this study.

\section{Study Design}

A total of twenty four (24) animals were used for this study, there animals were randomly grouped into four (4) groups with six (6) animals in each group.

\section{Group 1: Normal control}

Group 2: Negative control received 50mg/kg streptozotocin injection and remained untreated

Group 3: Positive control received 50mg/kg streptozotocin injection and treated with $100 \mathrm{mg} / \mathrm{kg}$ metformin

Group 4: Receive 50mg/kg streptozotocin injection and treated with $300 \mathrm{mg} / \mathrm{kg}$ delonix regia seed

\section{Determination of blood glucose levels}

All blood samples were collected from the tail vein of the rats at intervals of 7, 14 and 21days. Fasting blood glucose levels were determined by using glucose oxidase method $^{13}$ using a digital glucometer (Accu-Chek, Roche Diagnostic, Germany) and the results were expressed in the unit of $\mathrm{mg} / \mathrm{dL}$. After 72 hours of streptozotocin injection rats having fasting blood glucose levels greater than $224 \mathrm{mg} /$ $\mathrm{dL}$ were considered as diabetic.

\section{Biochemical analysis}

Randox kit method of enzymatic hydrolysis described by ${ }^{14}$ was used for estimating triglyceride, total cholesterol and high density lipoprotein-cholesterol. Serum level of alanine and aspartate aminotransferases (ALT and AST) and alkaline phosphatase (ALP) were quantified by spectroscopy using Randox commercial assay kits.

\section{Relative organ weight}

After three (3) weeks of treatment, the body weight of all the animals were weighed in grams using standard laboratory weighing balance after which there were euthanized by exsanguination under chloroform anesthesia. The liver was carefully dissected out and also weighed in grams (absolute organ weight). The relative organ weight of each animal was then calculated as follows: as described by. ${ }^{15}$

$$
\text { Relative Organ weight }=\frac{\text { Absolute organ weight }(g)}{\text { Body weight of rat }(g)} \times 100
$$

\section{Statistical analysis}

Data were treated by ANOVA (analysis of variance) and mean separation was done using Turkey HSD and Duncan. $\mathrm{p}<0.05$ was considered significant. Data was expressed as mean \pm standard deviation. All statistical analysis was done using IBM SPSS Version 22 and Microsoft Excel.

\section{Results}

\section{Blood sugar level}

Table 1 demonstrates the effect of aqueous seed extract of delonix regia on blood sugar levels of male wistar rats. Following two (2) weeks of acclimatization, there experimental groups were induced diabetes with a $50 \mathrm{mg} / \mathrm{kg}$ dose of intraperitoneal injection of streptozotocin. Consequently, the blood sugar levels were significantly elevated $\mathrm{p}<0.05$ for the experimental groups: negative control $(222.00 \pm 5.18)$, positive control $(225.00 \pm 4.52)$ and D. regia $(224.50 \pm 4.72)$ relative to the normal control $(90.50 \pm 3.33)$ which remained non-induced. Treatment followed after confirmation of hyperglycemia for a period of three (3) weeks. Week one, 300mg/ $\mathrm{kg}$ aqueous seed extract of delonix regia (223.33 \pm 4.13$)$ showed no significant decrease $\mathrm{p}<0.05$ in blood sugar levels relative to the negative control (227.00 \pm 5.18$)$. However, at week two (2) the extract $(164.17 \pm 4.49)$ showed a significant decrease $\mathrm{p}<0.05$ relative to the negative control (229.50 5.99$)$ and at week three (3) the extract show better potency as blood sugar level was significantly decreased similar to the group treated with standard drug $100 \mathrm{mg} / \mathrm{kg}$ metformin.

\section{Liver function}

Table 2 shows the effect of aqueous seed extract of $D$. regia on liver function and relative liver weight. After 21days of treatment, serum levels of selected liver function enzymes were determined and the normal levels of the enzymes and relative liver weight ranged

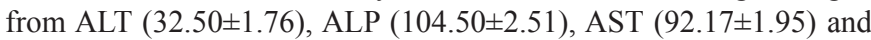
relative liver weight $(2.26 \pm 0.04)$. The negative control considered

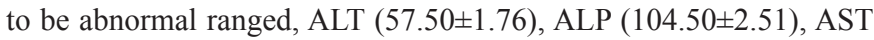
$(126.17 \pm 2.86)$ and relative liver weight $(3.21 \pm 0.03)$ respectively. However, the group treated with $300 \mathrm{mg} / \mathrm{kg}$ aqueous seed extract of $D$. regia significantly lowered $\mathrm{P}<0.05$ levels of the enzymes and relative liver weight relative to the negative control and the positive control a had similar trend.

\section{Lipid profile}

Figure 1, 2 and 3 respectively shows the effect of aqueous seed extract of $D$. regia on male wistar rat's lipid profile. Plasma levels of markers of lipid profile (cholesterol, triglycerides and high density 
lipoprotein) were determined from blood collected via orbital plexus on weekly interval for a period of three weeks. For cholesterol Figure 1, the normal levels ranged from week one (122.17 \pm 1.54$)$, week two (126.33 \pm 2.66$)$ and week three $(119.3 \pm 1.72)$ and negative control week one $(186.33 \pm 2.34)$, week two $(188.67 \pm 1.51)$ and week three $(194.33 \pm 2.34)$ and for triglyceride Figure 2, normal levels $(140.33 \pm 0.82),(137.33 \pm 1.03)$, and $(140.17 \pm 1.17)$ and negative control $(218.67 \pm 1.51),(210.17 \pm 1.60)$, and $(219.50 \pm 2.17)$ respectively. Thus, in each parameter assay, the Negative Control was significantly $\mathrm{p}<0.05$ higher than normal control and of course treatment with $300 \mathrm{mg} / \mathrm{kg}$ aqueous seed extract of $D$. regia significantly reduced $\mathrm{p}<0.05$ levels of CHOL and TRIG relative to the negative control. Conversely, Figure 3 showed that the levels of HDL was significantly higher $\mathrm{p}<0.05$ for $300 \mathrm{mg} / \mathrm{kg}$ aqueous seed extract of $D$. regia treated group relative to the negative control for all the weeks.

Table I Effect of aqueous seed extract of delonix regia on blood sugar levels of male wistar rats

\begin{tabular}{lllll}
\hline \multirow{2}{*}{ Groups } & \multirow{2}{*}{ After induction } & \multicolumn{2}{l}{ Treatment Duration } \\
\cline { 3 - 5 } & & Week one & Week two & Week three \\
\hline Normal control & $90.50 \pm 3.33^{\mathrm{a}^{*} \#}$ & $93.67 \pm 2.34^{\mathrm{a}^{*} \#}$ & $92.17 \pm 2.40^{\mathrm{a}^{* \#}}$ & $99.00 \pm 2.10^{\mathrm{a}^{* \#}}$ \\
Negative control & $222.00 \pm 5.18^{\mathrm{b}}$ & $227.00 \pm 5.18^{\mathrm{c}}$ & $229.50 \pm 5.99^{\mathrm{d}}$ & $224.83 \pm 9.04^{\mathrm{c}}$ \\
Positive control & $225.00 \pm 4.52^{\mathrm{b}}$ & $173.50 \pm 3.56^{\mathrm{b}}$ & $141.83 \pm 2.71^{\mathrm{b}}$ & $120.00 \pm 2.83^{\mathrm{b}}$ \\
Delonix regia & $224.50 \pm 4.72^{\mathrm{b}}$ & $223.33 \pm 4.13^{\mathrm{c}^{*}}$ & $164.17 \pm 4.49^{\mathrm{c}^{*}}$ & $124.33 \pm 4.63^{\mathrm{b \#}}$ \\
\hline
\end{tabular}

$\mathrm{n}=6$. Data are expressed as mean \pm SD: Mean values in the same column with different superscripts are significantly different at $p<0.05$. Significantly different $\mathrm{p}<0.05$ vs Positive Control and \# significantly different $\mathrm{p}<0.05$ vs Negative Control

Table 2 Effect of aqueous seed extract of delonix regia on liver function enzyme of male wistar rats

\begin{tabular}{lllll}
\hline Groups & ALT & ALP & AST & Relative Liver Weight \\
\hline Normal control & $32.50 \pm 1.76^{\mathrm{a}^{* \#}}$ & $104.50 \pm 2.5 \mathrm{l}^{\mathrm{a}^{* \#}}$ & $92.17 \pm 1.95^{\mathrm{a}^{*} \#}$ & $2.26 \pm 0.04^{\mathrm{a}^{* \#}}$ \\
Negative control & $57.50 \pm 1.76^{\mathrm{c}}$ & $199.17 \pm 2.00^{\mathrm{d}}$ & $126.17 \pm 2.86^{\mathrm{c}}$ & $3.21 \pm 0.03^{\mathrm{c}}$ \\
Positive control & $43.33 \pm 1.86^{\mathrm{b}}$ & $158.50 \pm 3.2 \mathrm{I}^{\mathrm{c}}$ & $104.83 \pm 3.76^{\mathrm{b}}$ & $2.54 \pm 0.07^{\mathrm{b}}$ \\
Delonix regia & $45.17 \pm 2.48^{\mathrm{b \#}}$ & $141.00 \pm 3.74^{\mathrm{b} \#}$ & $102.83 \pm 2.04^{\mathrm{b \#}}$ & $2.49 \pm 0.12^{\mathrm{b \#}}$
\end{tabular}

$\mathrm{n}=6$. Data are expressed as mean \pm SD: Mean values in the same column with different superscripts are significantly different at $\mathrm{p}<0.05$. Significantly different $p<0.05$ vs Positive Control and \# significantly different $\mathrm{p}<0.05$ vs Negative Control.Abbreviations denote ALT,Alanine Aminotransferase;ALP,Alkaline Phosphatase and AST, Aspartate Aminotransferase

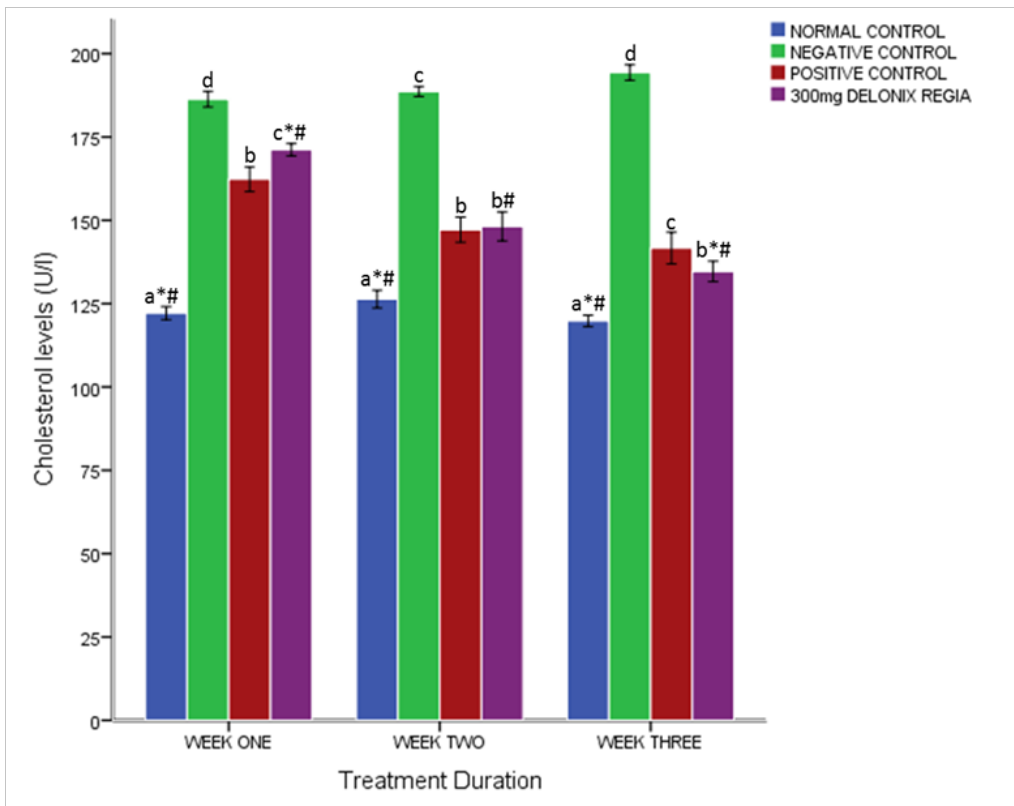

Figure I Effect of aqueous seed extract of delonix regia on Cholesterol levels of male wistar rats.

Bars with different alphabets (a, b, $c$ \& d) within the same variable are significant $P<0.05$. * Significantly different $\mathrm{p}<0.05$ vs Positive Control and \# significantly different $p<0.05$ vs Negative Control 


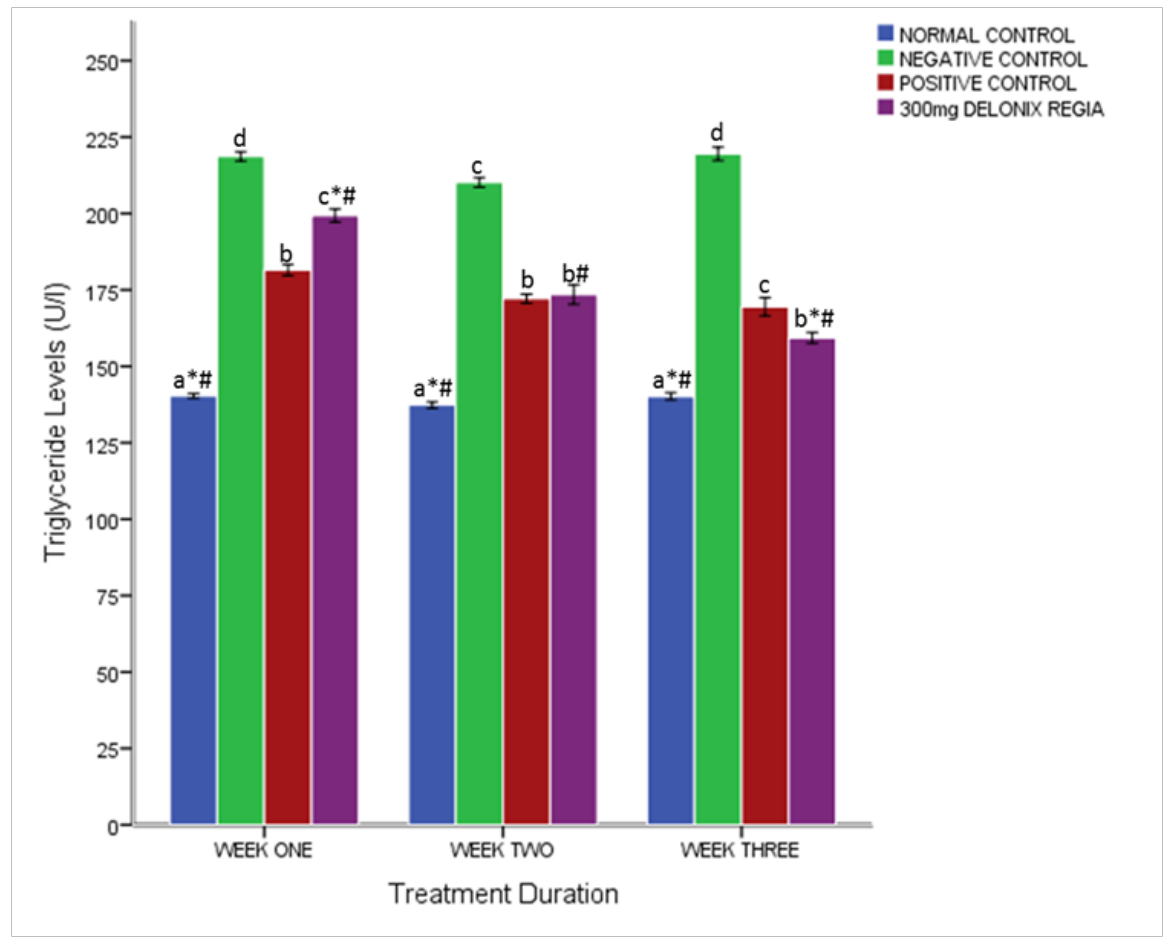

Figure 2 Effect of aqueous seed extract of delonix regia on Triglyceride levels of male wistar rats.

Bars with different alphabets ( $a, b, c$ \& d) within the same variable are significant $\mathrm{P}<0.05$. * Significantly different $\mathrm{p}<0.05$ vs Positive Control and \# significantly different $\mathrm{p}<0.05$ vs Negative Control

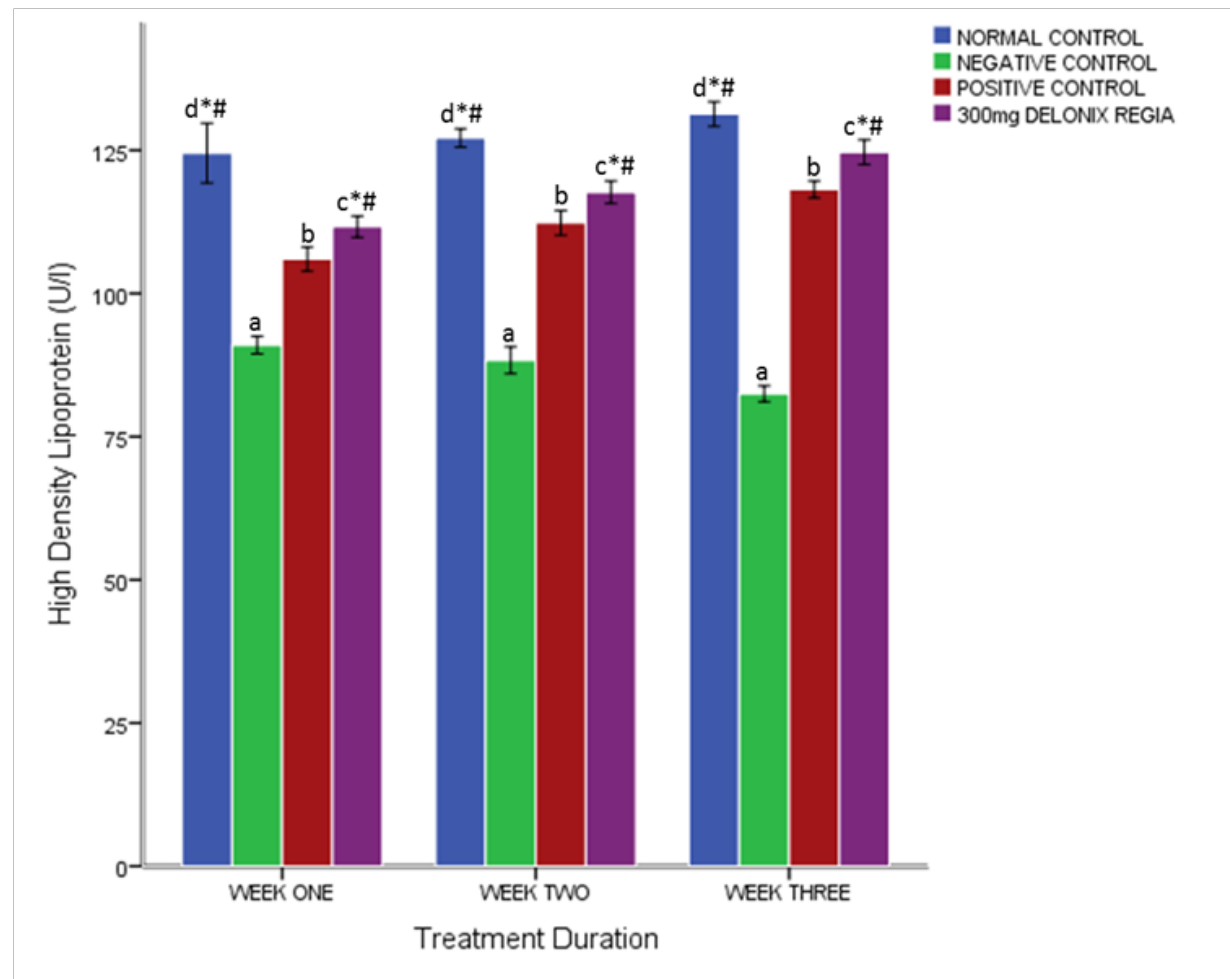

Figure 3 Effect of aqueous seed extract of delonix regia on High Density Lipoprotein levels of male wistar rats.

Bars with different alphabets (a, b, c \& d) within the same variable are significant $\mathrm{P}<0.05$. * Significantly different $\mathrm{p}<0.05$ vs Positive Control and \# significantly different $\mathrm{p}<0.05$ vs Negative Control. 


\section{Discussion}

Diabetes is a metabolic disorder characterized by an elevated blood sugar levels due to either destruction of pancreas or insensitivity of insulin. In this light, of course the result presented in table 1 demonstrated that there experimental groups had a significant $p<0.05$ blood sugar levels elevation after intraperitoneal injection of $50 \mathrm{mg} / \mathrm{kg} \mathrm{STZ}$ relative to the normal control (after induction) and this not a surprise as STZ has widely being the agent of choice for the induction of diabetes mellitus in animals for a long time now ${ }^{16}$ and the diabetogenic effects are due to selective destruction of pancreatic islet $\beta$-cells. ${ }^{17}$ After confirmation of diabetes, metformin was used a reference drug to ascertain the hypoglycemic ability of $300 \mathrm{mg} / \mathrm{kg}$ aqueous seed extract of $D$. regia for three weeks and of course delonix regia seed extracts have been shown to be a promising nutraceutical and a potent hypoglycemic agent. ${ }^{5,10}$ In corroboration to this reports, the present study revealed that the seed indeed possess hypoglycemic ability as the extract significantly $\mathrm{p}<0.05$ lowered blood sugar levels similar to the reference drug (metformin). Perhaps the hypoglycemic ability of aqueous seed extract of $D$. regia could be attributed to its functional phytoconstituents including flavonoids, alkaloids, saponins, sterols, $\beta$-sitosterol, lupeol, tannins, carotenoids, and phenolic acids. ${ }^{7}$

Enzyme activities in the tissues are often used as 'marker' to ascertain early toxic effects of administered foreign compounds to experimental animals. ${ }^{15,18}$ ALP is a membrane bound enzyme while ALT and AST are cytosolic enzymes and high levels of ALP, ALT and AST respectively in the serum are indicators of cell membrane permeability and consequent degree of damage to the liver. ${ }^{15,19}$ In this regards, the result of this study presented in Table 2, revealed that there levels of key liver function enzymes ALP, ALT, and AST respectively significantly increased $\mathrm{p}<0.05$ in the negative control vis-à-vis the normal control and indeed the activities of AST, ALT and ALP have been reported to increase in STZ induced diabetes. ${ }^{20-22}$ However, treatment of the experimental animals with $300 \mathrm{mg} / \mathrm{kg}$ aqueous seed extract of $D$. regia significantly $\mathrm{p}<0.05$ improved the liver integrity as levels of key liver enzymes and relative liver weight were significantly $\mathrm{p}<0.05$ lowered relative to the untreated group (negative control) and the hepatoprotective ability may be attributable to the antioxidant potential of the seed ${ }^{11}$ since hyperglycemia in diabetes mellitus leads to increased lipid peroxidation in the body, followed by the development of chronic complications due to oxidative stress. ${ }^{23}$ Our result on the hepatoprotective role of seed extract of $D$. regia corroborates the findings of. ${ }^{24,25}$

Diabetic dyslipidemia shows high levels of plasma cholesterol (CHOL), triglyceride (TRIG), LDL-cholesterol (LDL), and low HDL-cholesterol (HDL) concentrations ${ }^{26}$ and alterations in lipid metabolism can cause lipotoxicity, which can further exacerbate diabetic complications. ${ }^{27}$ In this light, of course the result of the present study (Figure 1, $2 \& 3$ ) revealed that the levels of CHOL and TRIG was significantly increased $\mathrm{p}<0.05$ for the negative control meanwhile HDL decreased vis-à-vis the normal control and among the established risk factors for coronary heart disease (CHD), the lipid triad (elevated triglyceride, Cholesterol levels and decreased HDLcholesterol concentrations) are there major predisposing factor for atherosclerosis in DM. ${ }^{28}$ However, $300 \mathrm{mg} / \mathrm{kg}$ aqueous seed extract of $D$. regia treatment significantly $\mathrm{p}<0.05$ enhanced the levels of lipid triad relative to the negative control across all there weeks. This result confirm $D$. regia seed an excellent therapeutic candidate for the management of DM and its related conditions and our finding is in consistent with the report of. ${ }^{5}$

\section{Conclusion}

In conclusion, our results demonstrate and validate the use of delonix regia seed, a good therapeutic candidate for the management of diabetes and also provide an insight on its use on diabetes related complications. Of course, blood sugar levels were reduced; key liver enzymes and lipid triad were respectively improved.

\section{Acknowledgments}

Authors with Madonna University affiliation are grateful to the department of biochemistry members of staff for the training and for providing the material resource for the successful completion of this work.

\section{Conflicts of interest}

Authors declare that there is no conflict of interest.

\section{References}

1. Global Report on Diabetes. World Health Organization; 2016. 88 p.

2. Riaz S. Diabetes mellitus. Scientific Research and Essay. 2009;4(5):367-373.

3. Seuring T, Olga A, Marc S. The Economic Costs of Type 2 Diabetes: A Global Systematic Review. Pharmacoeconomics. 2015;33(8):811-831.

4. Diabetes Atlas, 6th ed. Belgium: International Diabetes Federation; 2013.

5. Nagarajan SS, Muthusamy P, Radha R. Evaluation of anti-diabetic activity on ethanolic extract of Delonix regia seeds. International Journal of Advanced Research and Development. 2016;1(4):83-86.

6. Chikezie PC, Ojiako OA, Nwufo KC. Overview of Anti-Diabetic Medicinal Plants: The Nigerian Research Experience. J Diabetes Metab. 2015;6(6):1-7.

7. Wang LS, Lee CT, Su WL, et al. Delonix regia Leaf Extract (DRLE): A Potential Therapeutic Agent for Cardioprotection. PLoS One. 2016;11(12): e0167768.

8. Fatmawaty, Fadilah, Astuti H. Antimalarial activity of Delonix regia on mice with Plasmodium berghei. Journal of Natural Products. 2013;6:61-66

9. Vidyasagar GM, Prashantkumar P. Traditional herbal remedies for gynecological disorders in women of Bidar district, Karnataka, India. Fitoterapia. 2007;78(1):48-51.

10. Anacletus FC, Osuji PO, Monago CC. Effects of Metformin, Pioglitazone and Aqueous Extract of Delonix Regia on Blood Levels of Glycated Hemoglobin (Hba1c) of Streptozotocin-Induced Diabetic Male and Female Wistar Albino Rats. IOSR Journal of Biotechnology and Biochemistry. 2015;1(4):23-27.

11. Ogboye PO, Onyegeme-Okerenta BM, Monago-Ighorodje CC. Proximate Composition, Antioxidant and Hypoglycaemic Potential of Aqueous Extracts of Seeds of Delonix regia on High Fat Diet and StreptozotocinInduced Diabetes in Female Wistar Rats. Clinical and Experimental Medical Sciences. 2018;6(1):33-46.

12. Kaga BI, Dyek N, Kwasu LS, et al. Toxicological assessment of methanol extracts of Delonix regia seeds in weaner rabbits. International Journal of Innovative Research in Technology, Basic and Applied Sciences. 2015;2(1):100-104. 
13. Beach EF, Turner JJ. An enzymatic method for glucose determination uptake in body fluids. Clin Chem. 1958;4(6):462-468.

14. Richmond W. Preparation and properties of a cholesterol oxidase from Nocardia specie and its application to the enzymatic assay of total cholesterol in serum. Clin Chem. 1973;19(12):1350-1356.

15. Nwawuba SU, Okechukwu FC. The effect of Cyperus esculentus (Tigernut) oil on liver, kidney and hematological biomarkers in low dose streptozocin and high fat diet exposed male wistar rats. International Journal of Food Science and Nutrition. 2018;3(4):148-152.

16. Lenzen S. The mechanisms of alloxan and streptozotocin-induced diabetes Diabetologia. 2008;51(2):216-226.

17. Furman BL. Streptozotocin-Induced Diabetic Models in Mice and Rats Streptozotocin-Induced Diabetic Models. Curr Protoc Pharmacol. 2016;70(1):5.47.1-20.

18. Adesokan AA, Oyewole OI, Turay MS. Kidney and Liver Function Parameters in Alloxan-Induced Diabetic Rats Treated with Aloe Barbadensis Juice Extract. Sierra Leone Journal of Biomedical Research. 2009;1(1):33-37.

19. Nwozo SO, Adeneye DA, Nwawuba SU. Effect of Solanium melongena fruits supplemented diet on hyperglycemia, overweight, liver function and dyslipidemia in male New Zealand rabbits fed high fat and sucrose diet. Integrative Obesity and Diabetes. 2018;4(3):1-5.

20. Afrin RS, Arumugam V, Soetikno RA, et al. Curcumin ameliorates streptozotocin-induced liver damage through modulation of endoplasmic reticulum stress-mediated apoptosis in diabetic rats. Free Radic Res. 2015;49(3):279-289.

21. Kohl TN, Gehrke AS, Nagel M, et al. Diabetic liver injury from streptozotocin is regulated through the caspase- 8 homolog cFLIP involving activation of JNK2 and intrahepatic immunocompetent cells. Cell Death Dis. 2013;4(7):e712.
22. Omonkhua AA, Adebayo EA, Saliu JA, et al. Liver function of Streptozotocin- Induced Diabetic Rats Orally Administered Aqueous Root-Bark Extracts of Tetrapleura tetraptera (Taub). Nigerian Journal of Basic and Applied Science. 2014;22(3-4):99-106.

23. Ganjifrockwala FA, Joseph JT, George G. Decreased total antioxidant levels and increased oxidative stress in South African type 2 diabetes mellitus patients. Journal of Endocrinology, Metabolism and Diabetes of South Africa. 2017;22(2):21-25.

24. Onyegeme-Okerenta BM, Philip OO, Monago-Ighorodje CC. Ameliorative Effect of Aqueous Extracts of Seeds of Delonix regia (Hook) Raf on the Liver, Kidney and Spleen of High-fat Diet Streptozotocin-induced Diabetes in Female Wistar Rats. European Journal of Medicinal Plants. 2018;25(2):1-14.

25. Omeodu SI, Onyegeme-Okerenta BM, Amakiri AP. Effect of delonix regia seed extract on some liver enzyme markers and electrolytes of alloxaninduced diabetic rats. Journal of Pharmaceutical and Scientific Innovation. 2017;6(2):37-43.

26. Mooradian AD. Dyslipidemia in type 2 diabetes mellitus. Nat Clin Pract Endocrinol Metab. 2009;5(3):150-159.

27. Chang CL, Lin Y, Bartolome AP, et al. Herbal therapies for type 2 diabetes mellitus: chemistry, biology, and potential application of selected plants and compounds. Evid Based Complement Alternat Med. 2013;378657:1-33.

28. Temelkova-Kurktschiev T, Hanefeld M. The lipid triad in type 2 diabetesprevalence and relevance of hypertriglyceridemia/low high-density lipoprotein syndrome in type 2 diabetes. Exp Clin Endocrinol Diabetes. 2004;112(2):75-79. 